\title{
Gripping family tale lacks cache for physicians
}

\author{
The Immortal Life of Henrietta Lacks \\ Rebecca Skloot \\ Crown Publishing; 2010
}

$\mathrm{S}$ cience writer Rebecca Skloot has written an impressive piece of journalism in locating and tracing the woman (and her family) whose malignant cervical tissue supplied the remarkable HeLa cell line identified in 1951. These cancer cells defy the usual laws of limited replication; they are "immortal" in so far as this culture has never "died" and to this day serves as a prolific source of biological material for both basic and clinical scientists.

The author, displaying remarkable ingenuity, tenacity and admirable social skills manages to track down family members of the long deceased Henrietta Lacks (thus HeLa) and in this book recounts both parties' sad tale. Sad because the family and Henrietta herself are a classic case of the American black underclass in the middle of the last century, especially in the South: poverty stricken, undereducated, discriminated against and above all poorly and patchily covered by America's

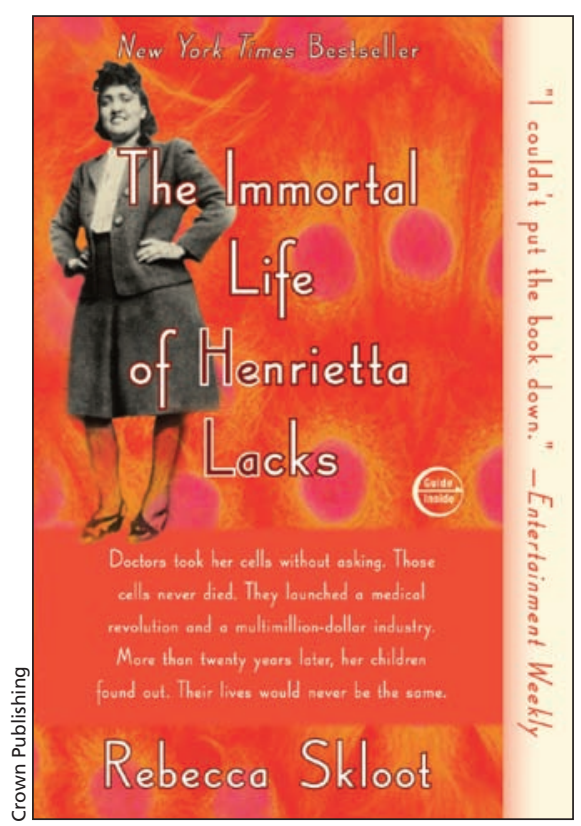

be, as a physician I found the book wanting. Henrietta's own tale is indeed compelling, but could have been recounted fully in a long magazine article. In fact, on the frontispiece, three such pieces by Skloot are listed and I refer the interested reader to them. In the book, the science of cell lines is described reasonably enough for a lay

\section{Skloot successfully plays up the human interest story while dumbing down the science.}

poor and patchy health care system. Henrietta's daughter Deborah, about whom most of the book actually revolves, puts it so well when she says, "But I always have thought it was strange, if our mother cells done so much for medicine, how come her family can't afford to see no doctors? Don't make no sense."

Gripping as the family's story may person, but does not provide the physician with any new insights. As a social history, as mentioned, there is a moral, but we are already sadly well acquainted with the travails of the American health care system.

Although Lacks was treated in the segregated "coloured" wards of the 1950s Johns Hopkins Hospital, there is no evidence that she received substan- dard care for the time. Nor does the fact that the cervical biopsy was sent off without her consent to researchers at Johns Hopkins seem a particularly egregious act to me - except perhaps through the lens of a moral "retrospectoscope." This was standard practice for the time. While it is true that later on, medical supply companies offering the cell line for sale made a profit, neither the researchers involved nor the institution did.

The book has been a smash success, including attaining bestseller status (in hardcover), no mean feat in today's publsihing world, which is dominated by electronic book readers. However, I have the uncomfortable feeling that the book plays on an unholy combination of the lay public's curiosity about the "victims" of modern medicine, together with a distrust of physicians and of medical research. With Oprah-like sentimentality, Skloot successfully plays up the human interest story while dumbing down the science.

The theme, spirit and style of the book are well delineated on the jacket cover: "Doctors took her cells without asking. Those cells never died. They launched a medical revolution and a multimillion-dollar industry. More than twenty years later, her children found out. Their lives would never be the same." [italics in original]

At risk of appearing aloof and insensitive, my feeling is that as a physician, if you pass on this book your life will still be very much the same.

\section{A. Mark Clarfield MD \\ Director of Geriatrics \\ Soroka Hopsital and Ben-Gurion \\ University \\ Beer-sheva, Israel}

CMAJ 2012. DOI:10.1503/cmaj.110889 